\title{
Functional Changes of Glial Glutamate Transporter GLT-1 during Ischemia: An In Vivo Study in the Hippocampal CA1 of Normal Mice and Mutant Mice Lacking GLT-1
}

\author{
Akira Mitani ${ }^{1}$ and Kohichi Tanaka ${ }^{2,3}$ \\ ${ }^{1}$ College of Medical Technology, Kyoto University, Shogoin, Sakyo-ku, Kyoto 606-8507, Japan, ${ }^{2}$ Laboratory of Molecular Neuroscience, School of \\ Biomedical Science and Medical Research Institute, Tokyo Medical and Dental University, Bunkyo-ku, Tokyo 113-8579, Japan, and ${ }^{3}$ Precursory Research \\ for Embryonic Science and Technology, Japan Science and Technology Corporation, Kawaguchi, Saitama 332-0012, Japan
}

\begin{abstract}
Glutamate transporters remove glutamate from the extracellular space and maintain it below neurotoxic levels under normal conditions. However, the dynamics under ischemic conditions remain to be determined. In the present study, we evaluated the function of the glial glutamate transporter (GLT-1) during brain ischemia by using an in vivo brain microdialysis technique in GLT-1 mutant mice. A microdialysis probe was placed in the hippocampal CA1 of GLT-1 mutant and wild-type mice, and glutamate levels were measured during 5 and 20 min ischemia. The glutamate levels in mice lacking GLT-1 were significantly higher than the corresponding glutamate levels in wild-type mice during $5 \mathrm{~min}$ ischemia. Delayed neuronal death was induced in the CA1 of the mice lacking GLT-1 but not in the CA1 of the wild-type mice. When ischemia was elongated to the duration of $20 \mathrm{~min}$, the glutamate levels in wild-type mice were significantly higher than the corresponding glutamate levels in mice lacking GLT-1 during the last $12.5 \mathrm{~min}$ of $20 \mathrm{~min}$ ischemia. Acute neuronal death was also observed in the CA1 of wild-type mice. These results suggest that GLT-1 takes up extracellular glutamate to protect neurons in the early stage of ischemia and then releases glutamate, triggering acute neuronal death, when ischemic conditions are elongated. The function of GLT-1 may change from neuroprotective to neurodegenerative during ischemia.
\end{abstract}

Key words: glutamate transporter; glia; GLT-1; knock-out mouse; hippocampal CA1; ischemia; neuronal death; microdialysis

\section{Introduction}

Increased extracellular glutamate during ischemia triggers the death of neurons (Rothman and Olney, 1986; Choi and Rothman, 1990). The neurotoxicity of glutamate has been shown to be mediated by glutamatergic presynaptic terminals (Wieloch et al., 1985; Kaplan et al., 1989), glutamate receptors (PellegriniGiampietro et al., 1992; Mitani et al., 1998a,b), and glutamate transporters (Rossi et al., 2000; Rao et al., 2001; Hamann et al., 2002); however, the mechanism of glutamate increase has not been established. Glutamate transport is the only mechanism for the removal of glutamate from the extracellular fluid in the brain (Kanai et al., 1997; Lehre and Danbolt, 1998; Tanaka, 2000) and is essential for maintaining extracellular glutamate below neurotoxic levels in the normal brain (Attwell et al., 1993). Therefore, glutamate transporters are thought to play a pivotal role in the process of increase in extracellular glutamate during ischemia.

The genes for glutamate transporters have been cloned, and at least five subtypes have been identified: GLAST-EAAT1 (Storck et al., 1992; Tanaka, 1993), GLT-1-EAAT2 (Pines et al., 1992),

\footnotetext{
Received March 17, 2003; revised June 5, 2003; accepted June 12, 2003.

This work was supported in part by grants-in-aid for scientific research from the Japan Society for the Promotion of Science and the Ministry of Health, Labour, and Welfare of Japan. We thank K. Okugawa for help in animal experiments, T. Yagi for photographic help, and D. Shimizu for help in histological experiments.

Correspondence should be addressed to Dr. Akira Mitani, College of Medical Technology, Kyoto University, 53 Kawahara-cho, Shogoin, Sakyo-ku, Kyoto 606-8507, Japan. E-mail: amitani@itan.kyoto-u.ac.jp. Copyright $\odot 2003$ Society for Neuroscience $\quad$ 0270-6474/03/237176-07\$15.00/0
}

EAAC1-EAAT3 (Kanai and Hediger, 1992), EAAT4 (Fairman et al., 1995), and EAAT5 (Arriza et al., 1997). It has been reported that GLT-1 (glial glutamate transporter) and GLAST are localized to glial cells (astrocytes), whereas EAAC1, EAAT4, and EAAT5 are localized to neurons (Rothstein et al., 1994; Chaudhry et al., 1995; Pow et al., 2000), and that the maintenance of low extracellular glutamate levels is sustained by glial transporters but not neuronal transporters (Rothstein et al., 1996; Peghini et al., 1997). The regional distributions of the glial transporters are unique to each transporter subtype in the brain. GLT-1 is highest in the hippocampus, whereas GLAST is highest in the cerebellar cortex (Rothstein et al., 1994; Chaundhry et al., 1995; Lehre et al., 1995). Therefore, the extracellular glutamate level in the hippocampal CA1 that is most sensitive to neuronal degeneration to ischemia is thought to be maintained primarily by GLT-1.

Several studies have examined the role of GLT-1 in ischemia using specific pharmacological blockers or antisense oligodeoxynucleotides; however, the results are controversial. A pharmacological study has shown that the GLT-1 blocker reduces the ischemia-induced glutamate release in rat cortical superfusates (Phillis et al., 2000), suggesting that GLT-1 releases glutamate during ischemia. In contrast, a study using antisense oligodeoxynucleotides has demonstrated that the antisense knockdown of GLT-1 exacerbates ischemia-induced neuronal damage in the rat brain (Rao et al., 2001), suggesting that GLT-1 takes up glutamate to protect neurons during ischemia. 
Recently, we generated mice lacking GLT-1 by using homologous recombination (Tanaka et al., 1997). The mice, despite depletion of the gene for GLT-1, did not show any significant changes in the expression of the other major glial glutamate transporter GLAST in young (Voutsinos-Porche et al., 2003) and adult stages (our unpublished observations), as compared with their corresponding wild-type mice. In the present study, we performed in vivo brain microdialysis experiments in the hippocampal CA1 of mice lacking GLT-1 and investigated how GLT-1 functions during the increase in extracellular glutamate during ischemia.

\section{Materials and Methods}

Animals and surgery. The experiments were conducted in accordance with the guidelines for animal experimentation at Ehime University School of Medicine and College of Medical Technology (Kyoto University). In principle, the method was the same as described in previous studies (Mitani et al., 1992, 1994). In brief, C57BL/6 mice lacking GLT-1 gene expression and wild-type mice (12-16 weeks old) were given access to food and water ad libitum. The animals were anesthetized and maintained with a mixture of $2.5 \%$ halothane and nitrous oxide/oxygen ( $7: 3)$. The common carotid arteries were exposed on both sides, and a 4-0 silk suture was looped around each artery. The head of the animal was held in a stereotaxic apparatus (type 1430; David Kopf, Tujunga, CA). A burr hole for insertion of a microdialysis probe into the CAl of the hippocampus was made $1.3-2.8 \mathrm{~mm}$ caudal to the bregma and $1-2.5 \mathrm{~mm}$ lateral to the midline. A second burr hole for insertion of a laser-Doppler flowmetry needle-probe was made $3.6-4.6 \mathrm{~mm}$ caudal to the bregma and 3-4 mm lateral to the midline. A third burr hole for insertion of a thermocouple needle-probe was made $1-2 \mathrm{~mm}$ rostral to the bregma and 1-2 $\mathrm{mm}$ lateral to the midline. The dura was carefully incised.

Ischemia and brain microdialysis. In the present study, bilateral occlusion of the common carotid arteries (BCCA) was used to induce ischemia in the hippocampus. Generally, satisfactory ischemia with blood flow below $10 \%$ of the baseline (Panahian et al., 1996) cannot be accomplished in the hippocampus of mice only by BCCA occlusion, because blood flow from the vertebral arteries will be supplied to the hippocampus through the circle of Willis. Recently, however, it has been reported that a satisfactory ischemic condition is frequently produced in the hippocampus of $\mathrm{C} 57 \mathrm{BL} / 6$ mice with only occlusion of BCCA, because C57BL/6 mice frequently lack or have poorly developed vascular connections between the carotid and basilar arteries (Fujii et al., 1997; Yang et al., 1997). We then monitored blood flow in the hippocampus during microdialysis experiments and confirmed whether BCCA occlusion induced satisfactory ischemia. A laser-Doppler flowmeter (TBF-LN1; Unique Medical Company, Tokyo, Japan) and a laser-Doppler needle probe of $0.5 \mathrm{~mm}$ diameter (LP-N; Unique Medical Company) were used to monitor relative changes in the blood flow in the hippocampus. The flowmetry probe was inserted in the caudal portion of the hippocampus (3.5 mm caudal to the bregma, $3.5 \mathrm{~mm}$ lateral to the midline, and depth of $1.8 \mathrm{~mm}$ from the cortical surface) at a $20^{\circ}$ angle caudal to the vertical plane. The changes in blood flow were monitored continuously. The mean blood flow for $1 \mathrm{~min}$ immediately before BCCA occlusion was taken as $100 \%$ to establish the baseline value, and subsequent flow changes were expressed relative to the value. The mean rate of blood flow during occlusion was obtained as average rates of blood flow every $10 \mathrm{sec}$. We accepted data from animals in which the blood flow decreased consistently below $10 \%$ of the baseline during occlusion.

A thermocouple needle probe of $0.4 \mathrm{~mm}$ diameter (TN-800S; Unique Medical Company) and a thermocouple meter (TME-300; Unique Medical Company) were used to monitor brain temperature. The thermocouple probe was inserted in the brain (1.2 $\mathrm{mm}$ rostral to the bregma, 1.5 $\mathrm{mm}$ lateral to the midline, and depth of $1.8 \mathrm{~mm}$ from the cortical surface) at a $15^{\circ}$ angle rostral to the vertical plane. An identical thermocouple needle probe and thermocouple meter assembly was used to monitor the rectal temperature. The body and brain temperatures were regulated at $37 \pm 0.3^{\circ} \mathrm{C}$ with a heating blanket (Harvard Apparatus, Kent, England) and overhead heating fan (Panasonic, Tokyo, Japan) during the experiments.

A microdialysis probe $(0.5-\mathrm{mm}$-long dialysis membrane, $0.22 \mathrm{~mm}$ diameter; molecular weight cutoff, 50,000) (A-I-4-005; Eicom, Kyoto, Japan) was positioned perpendicularly in the CA1 (1.8-2.3 mm caudal to the bregma, $1.5-2.2 \mathrm{~mm}$ lateral to the midline, and $1.5-1.6 \mathrm{~mm}$ ventral to the cortical surface). Subsequently, the microdialysis probe was perfused with Ringer's solution at a flow rate of $0.6 \mu \mathrm{l} / \mathrm{min}$ by means of a microinfusion pump (Bioresearch Center, Nagoya, Japan). After a $2 \mathrm{hr}$ stabilization period, halothane administration was decreased to $1 \%$ and then transient forebrain ischemia of 5 or 20 min duration was induced. The sutures around the two common carotid arteries were pulled using $6 \mathrm{gm}$ weights to occlude the circulation. After ischemia, the sutures were cut and removed to restore blood flow.

Samples ( $150 \mathrm{sec} ; 1.5 \mu \mathrm{l}$ ) of the dialysate were collected consecutively. In mice subjected to $5 \mathrm{~min}$ ischemia, six samples were collected before ischemia, two samples were collected during ischemia, and 14 samples were collected after ischemia. In mice subjected to $20 \mathrm{~min}$ ischemia, six samples were collected before ischemia, eight samples were collected during ischemia, and 16 samples were collected after ischemia. After the collection of dialysate samples, the probes for microdialysis, flowmetry, and thermomonitor were gently removed. All surgical incisions were carefully sutured. The animals were treated with antibiotics, removed from the stereotaxic apparatus, and put into a comfortable position on a warming blanket. After awakening, the animals were returned to individual cages in a room maintained at a constant temperature $\left(26^{\circ} \mathrm{C}\right)$ and allowed access to food and water ad libitum. Other sets of wild-type mice served as sham-operated controls in which the animals were subjected to identical procedures, except that the sutures around the common carotid arteries were not pulled.

Glutamate assay. The present enzymatic cycling procedure for glutamate assay was essentially the same as described in previous studies (Mitani et al., 1990, 1994). In brief, all sampling tubes were centrifuged to produce a bolus of dialysate at the bottom of the tubes immediately after collection, and glutamate was analyzed by the following serial enzymatic reactions. The dialysate $(1.5 \mu \mathrm{l})$ was reacted first with $7.5 \mu$ l of enzymatic reagent to form nicotinamide adenine dinucleotide phosphate (NADH). The reagent contained $0.1 \mathrm{~m}$ hydrazine buffer, $\mathrm{pH} 9.0$ (Wako Chemicals, Osaka, Japan), $0.4 \mathrm{~mm} \mathrm{NAD}^{+}$(Sigma, St. Louis, MO), $0.3 \mathrm{~mm} \mathrm{ADP}$ (Sigma), and $20 \mu \mathrm{g} / \mathrm{ml}$ of beef liver glutamate dehydrogenase (EC 1.4.1.3; Roche Products, Hertforshire, UK; Boehringer Mannheim, Mannheim, Germany). The mixture was incubated at $37^{\circ} \mathrm{C}$ for $30 \mathrm{~min}$, and the reaction was stopped by the addition of $1.8 \mu \mathrm{l}$ of $1 \mathrm{M} \mathrm{NaOH}$ followed by heating at $60^{\circ} \mathrm{C}$ for $20 \mathrm{~min}$. Subsequently, for triplicate determinations, three $3 \mu \mathrm{l}$ aliquots were transferred into fluorometer tubes and used for $\mathrm{NAD}^{+}-\mathrm{NADH}$ cycling by means of enzymatic cycling reactions (Kato et al., 1973; Nitsch and Okada, 1979). Thirty microliters of the second reagent was added into the tubes. The reagent contained $0.1 \mathrm{M}$ Tris- $\mathrm{HCl}$ buffer, pH 8.0 (Wako Chemicals), 0.02\% (v/v) 2-mercaptoethanol (Wako Chemicals), $0.02 \%(\mathrm{w} / \mathrm{v})$ bovine serum albumin (Sigma), $1.8 \%$ (v/v) ethanol (Wako Chemicals), 12 mm oxaloacetic acid (Wako Chemicals), $50 \mu \mathrm{g} / \mathrm{ml}$ of alcohol dehydrogenase (EC 1.1.1.1; Roche Products), and $2.5 \mu \mathrm{g} / \mathrm{ml}$ of malate dehydrogenase (EC 1.1.1.37; Roche Products). The tubes were incubated at $37^{\circ} \mathrm{C}$ for $60 \mathrm{~min}$. The tubes were heated at $100^{\circ} \mathrm{C}$ for $5 \mathrm{~min}$ to stop the reaction. In the indicator reaction, $0.6 \mathrm{ml}$ of the third reagent containing $0.5 \mathrm{~m}$ hydrazine buffer, $\mathrm{pH} 9.0,0.2 \mathrm{~mm}$ $\mathrm{NAD}^{+}$, and $2 \mu \mathrm{g} / \mathrm{ml}$ of malate dehydrogenase was added to the fluorometer tubes. The tubes were incubated at $26^{\circ} \mathrm{C}$ for $30 \mathrm{~min}$, and the fluorescence of NADH was measured with a fluorometer (F-2500; Hitachi, Tokyo, Japan). Glutamate standards of $0.05-100 \times 10^{-12} \mathrm{~mol} / \mu \mathrm{l}$ (Wako Chemicals) were quantified in parallel with the samples in each experiment, and glutamate concentrations of samples were read from the standard curve. The sensitivity was $0.05-0.1 \mathrm{pmol} / \mu \mathrm{l}$.

Histological analysis. The animals subjected to $5 \mathrm{~min}$ ischemia were deeply anesthetized with pentobarbital and perfused transcardially with heparinized saline $(5 \mathrm{ml})$ and then with $10 \%$ formalin in $0.1 \mathrm{M}$ phosphate buffer, pH $7.4(50 \mathrm{ml})$, at $1 \mathrm{hr}, 24 \mathrm{hr}$, or $4 \mathrm{~d}$ after recirculation. The animals subjected to $20 \mathrm{~min}$ ischemia were anesthetized and perfused with the same procedure at $1 \mathrm{hr}$ after recirculation. The brains were 


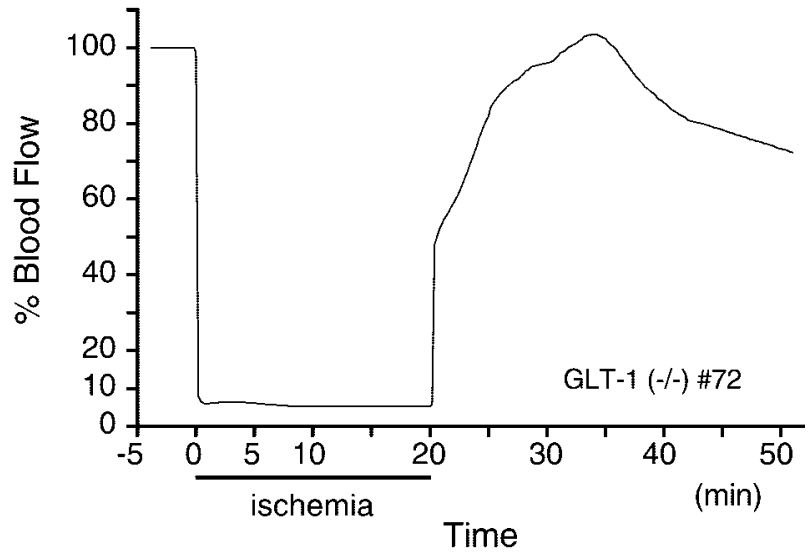

Figure 1. A representative change in hippocampal blood flow in mice subjected to $20 \mathrm{~min}$ of BCCA occlusion. Blood flow was recorded from the hippocampus at a distance of $\sim 1 \mathrm{~mm}$ caudal to the microdialysis probe. Blood flow decreased to $6.1 \%$ (mean) of the baseline during occlusion in a mouse lacking GLT-1 (number 72). Time 0 represents the point of onset of BCCA occlusion.

removed and processed for paraffin embedding. Serial coronal $5 \mu \mathrm{m}$ sections were cut and stained with cresyl violet to examine the intensity of ischemic injury and the position of the microdialysis probe. The intensity of the ischemic injury was quantitatively determined by counting the number of normal-appearing neurons (distinct cell membrane, well defined nucleus, and nucleolus) at $400 \times$ magnification in a blind manner. Cell counts were performed in the section close to the track of the microdialysis probe but did not include any mechanical damage produced by insertion of the probe, and the number of normal-appearing neurons along a $1 \mathrm{~mm}$ linear length of the hippocampal CA1 pyramidal cell layer was calculated.

Data analysis. ANOVA was used for the statistical analysis of glutamate levels and the number of normal-appearing neurons; this analysis included Scheffé's or Dunnett's multiple-comparison procedure. Data were presented as the mean \pm SEM. The differences discussed in the text were significant at $p<0.01$ or $p<0.05$.

\section{Results}

It has been known that GLT-1 mutant mice sometimes show spontaneous epileptic seizures and, in most cases, die within a few minutes of seizure onset (Tanaka et al., 1997). However, the GLT-1 mutant mice under anesthesia did not show any spontaneous or ischemia-induced epileptic seizures. Any convulsive medications were not used in the present study.

\section{Blood flow}

Microdialysis experiments were performed on $151 \mathrm{C} 57 \mathrm{BL} / 6$ mice (69 GLT-1 mutant mice and 82 wild-type mice, including 20 sham-operated controls), and the blood flow in the hippocampus decreased consistently below $10 \%$ of the baseline during occlusion of BCCA in 40 mice (20 GLT-1 mutant mice and 20 wildtype mice) (Fig. 1). In these animals, the blood flow decreased promptly after the onset of BCCA occlusion and remained constant throughout ischemia. No significant differences in the reduction of the blood flow were detected between GLT-1 mutant mice and wild-type mice $[8.3 \pm 0.3$ and $8.1 \pm 0.2 \%$ of the baseline in mutant mice $(n=12)$ and wild-type mice $(n=12)$ subjected to 5 min occlusion, respectively; $7.8 \pm 0.4$ and $7.9 \pm 0.4 \%$ of the baseline in mutant mice $(n=8)$ and wild-type mice $(n=8)$ subjected to $20 \mathrm{~min}$ occlusion, respectively]. After releasing the occlusion, the return of blood flow to the baseline was delayed for $\sim 5 \mathrm{~min}$ after $5 \mathrm{~min}$ ischemia and $\sim 10 \mathrm{~min}$ after $20 \mathrm{~min}$ ischemia, respectively, and thereafter a transient phase of relative hyper-

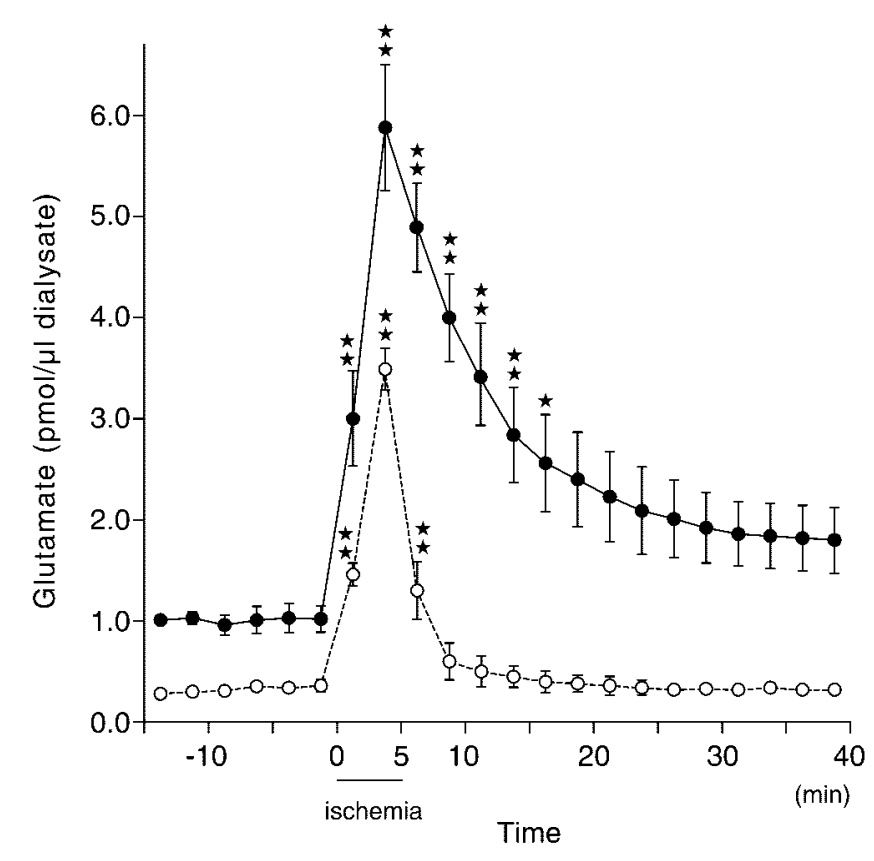

Figure 2. Changes in dialysate levels of glutamate in the hippocampal CA1 of mice lacking GLT-1 and wild-type mice. The mice were subjected to $5 \mathrm{~min}$ ischemia. The data presented are means \pm SEM (bars). Glutamate levels in mice lacking GLT-1 $(n=12 ;-0)$ were significantly higher than the corresponding glutamate levels in wild-type mice $(n=12 ; \bigcirc-\bigcirc)$ at all measured points ( $p<0.01$; two-way ANOVA; Scheffé's posthoc test). Asterisks indicate a value significantly higher than the corresponding preischemic levels in each group ( $\star \star p<0.01$; $\star p<0.05$; one-way ANOVA; Dunnett's post hoc test). Ordinate, Glutamate levels ( $\mathrm{pmol} / \mu \mathrm{l}$ ) in dialysate; abscissa, time ( $\mathrm{min}$ ) before and after the onset of $5 \mathrm{~min}$ ischemia.

emia developed and was followed by postischemic hypoperfusion. The time course of the blood flow changes was the same as reported in previous studies (Kuroiwa et al., 1992; Von Lubitz et al., 1995).

\section{Glutamate changes induced by $5 \mathrm{~min}$ ischemia}

In wild-type mice subjected to 5 min ischemia $(n=12)$, stable basal levels of glutamate were observed in six consecutive samples collected before ischemia (Fig. 2). A significant increase in glutamate was detected in the dialysate during ischemia. The increase was acute, and the maximal levels were attained at the end of 5 min ischemia. An $\sim 11$-fold increase was observed. After the onset of recirculation, the glutamate levels quickly decreased. Glutamate levels returned to the baseline range within $5 \mathrm{~min}$ of recirculation. The time course of the change of extracellular glutamate levels shown in wild-type mice was very similar to that shown in the hippocampal CA1 of gerbils subjected to $5 \mathrm{~min}$ ischemia (Mitani et al., 1992, 1994). In sham-operated control mice $(n=12)$, stable low levels of glutamate were observed at all measured points (data not shown), similar to the glutamate levels observed before ischemia in wild-type mice.

Glutamate levels in GLT-1 mutant mice subjected to $5 \mathrm{~min}$ ischemia $(n=12)$ were significantly higher than the corresponding glutamate levels in wild-type mice subjected to $5 \mathrm{~min}$ ischemia at all measured points, including before ischemia $(p<0.01$; two-way ANOVA; Scheffé's post hoc test) (Fig. 2). In mice lacking GLT-1, stable basal levels of glutamate were observed in the six consecutive samples collected before ischemia. However, the preischemic basal levels of glutamate were approximately three times as high as those in wild-type mice. A significant increase in glutamate was detected during ischemia and the early period of re- 

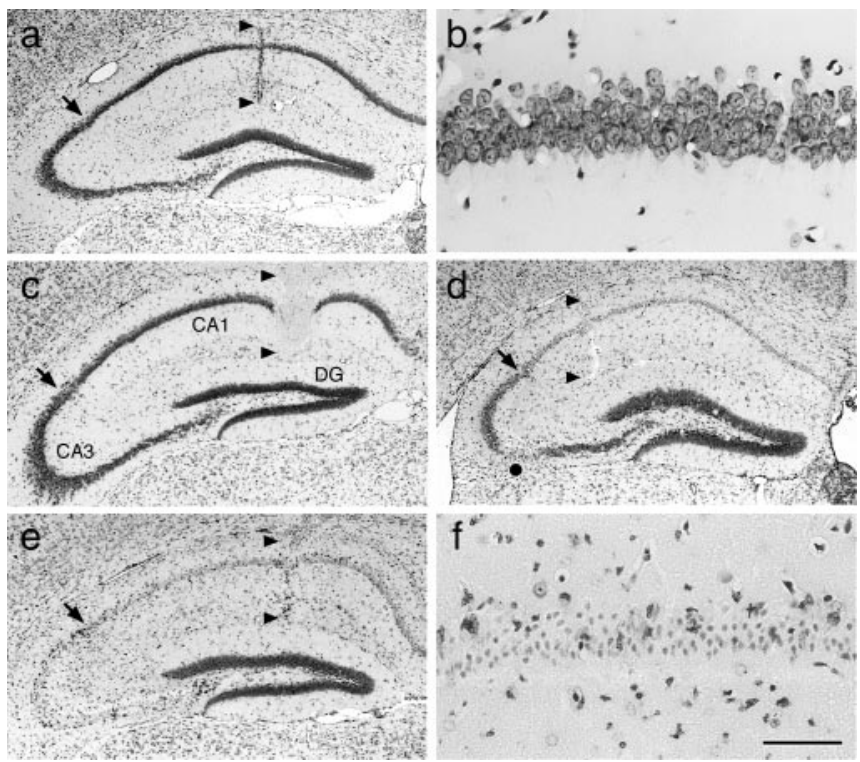

Figure 3. Photomicrographs showing the track of the microdialysis probe and neuronal death in the hippocampus of mice subjected to $5 \mathrm{~min}$ ischemia. In wild-type mice $(a, b)$, neuronal death was not observed $4 \mathrm{~d}$ after recirculation $(a)$. The higher magnification of the CA1 pyramidal cell layer shows that normal-appearing CA1 neurons are distributed densely in the layer $(b)$. In mice lacking GLT-1 (c-- f), neuronal death was not detected in the CA1 $1 \mathrm{hr}$ after recirculation (c). However, neuronal death was induced in the CA1 and also in part of the CA3 (around a filled circle) $24 \mathrm{hr}$ after recirculation ( $d$ ), and then widespread neuronal death was observed in the CA1 and CA3 $4 \mathrm{~d}$ after recirculation (e). The high magnification of the CA1 pyramidal cell layer $4 \mathrm{~d}$ after recirculation shows that almost all of the CA1 neurons died $(f) . a$, $c-e, A$ portion of the microdialysis membrane (distance between two arrowheads) was placed in the CA1. The arrows indicate the boundary between the CA1 and CA3. Scale bars: $a, c, d, e, 0.5$ $\mathrm{mm} ; b, f, 50 \mu \mathrm{m}$. DG, Dentate gyrus.

circulation. The increase was acute and massive, and the maximal levels were attained at the end of $5 \mathrm{~min}$ ischemia. The glutamate levels at the end of ischemia showed a sixfold increase and were approximately twice as high as those in wild-type mice. After the onset of recirculation, the glutamate levels in mice lacking GLT-1 decreased gradually, compared with the decline of glutamate levels in wild-type mice. The glutamate levels in mice lacking GLT-1 were significantly higher than the preischemic basal levels for 12.5 min after recirculation, whereas the glutamate levels in wildtype mice were significantly higher than the preischemic basal levels only for $2.5 \mathrm{~min}$ after recirculation (Fig. 2). The glutamate levels in mice lacking GLT-1 showed a tendency to be higher than the preischemic basal levels from $12.5 \mathrm{~min}$ after recirculation to the end of the measurement; however, the differences were not statistically significant.

\section{Neuronal damage induced by 5 min ischemia}

In wild-type mice subjected to $5 \mathrm{~min}$ ischemia, no definite neuronal changes were seen in the CA1 at $1 \mathrm{hr}, 24 \mathrm{hr}$, or $4 \mathrm{~d}$ after recirculation (Fig. $3 a$ ). Dense normal-appearing neurons were observed in the CA1 pyramidal cell layer (Fig. $3 b$ ). The neuronal densities at $1 \mathrm{hr}, 24 \mathrm{hr}$, and $4 \mathrm{~d}$ after recirculation were $232.2 \pm$ $3.3 / \mathrm{mm}(n=4), 230.7 \pm 3.1 / \mathrm{mm}(n=4)$, and $234.0 \pm 3.3 / \mathrm{mm}$ $(n=4)$, respectively. No significant differences in the number of normal-appearing neurons were detected between wild-type ischemic mice and sham-operated control mice (Fig. 4).

In GLT-1 mutant mice subjected to $5 \mathrm{~min}$ ischemia, no detectable changes were seen in the CA1 $1 \mathrm{hr}$ after recirculation (Fig. $3 c)$. The neuronal density $(232.4 \pm 3.2 / \mathrm{mm} ; n=4)$ was not significantly different from that in wild-type and sham-operated

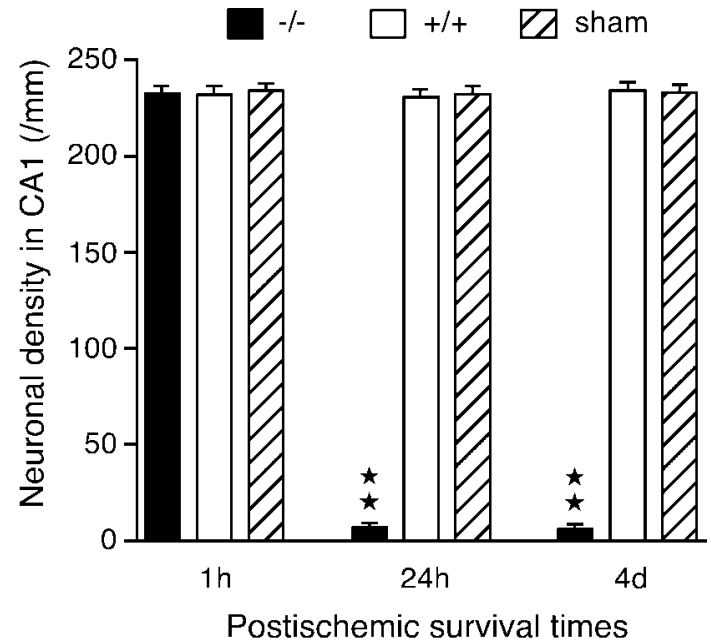

Figure 4. Neuronal density in the CA1 of mice subjected to $5 \mathrm{~min}$ ischemia. Normalappearing neurons were counted in the CA1 of mice lacking GLT-1 (-/-, filled columns), wild-type mice ( $+/+$, open columns), and sham-operated control mice (sham, stippled columns) $1 \mathrm{hr}, 24 \mathrm{hr}$, and $4 \mathrm{~d}$ after recirculation, and the density of neurons per millimeter in the pyramidal cell layer was calculated. The sham-operated control mice were $+/+$. Asterisks indicate a value significantly lower than the corresponding values in wild-type and shamoperated control mice ( $\star \star p<0.01$; one-way ANOVA; Scheffé's post hoc test). Values are means \pm SEM (bars) (each column, $n=4$ ).

control mice (Fig. 4). Twenty-four hours after recirculation, neuronal loss was detected in the CA1 and also in part of the CA3 (Fig. $3 d$ ). Normal-appearing neurons were rarely observed in the CA1 pyramidal cell layer (Fig. 4). Four days after recirculation, neuronal loss was seen throughout the CA1 and the CA3 (Fig. 3e), and normal-appearing neurons were rarely observed in the pyramidal cell layers (Fig. $3 f$ ). The neuronal densities in the CA1 pyramidal cell layer $24 \mathrm{hr}$ and $4 \mathrm{~d}$ after recirculation were $7.2 \pm$ $1.7 / \mathrm{mm}(n=4)$ and $6.3 \pm 1.6 / \mathrm{mm}(n=4)$, respectively. These densities were significantly less than the corresponding densities in wild-type and sham-operated control mice ( $p<0.01$; oneway ANOVA; Scheffé's post hoc test) (Fig. 4).

\section{Glutamate changes induced by $20 \mathrm{~min}$ ischemia}

In sham-operated control mice $(n=8)$, stable low levels of glutamate were observed at all measured points (data not shown). Glutamate levels in GLT-1 mutant mice subjected to $20 \mathrm{~min}$ ischemia $(n=8)$ that were stable before ischemia increased abruptly after the onset of ischemia (Fig. 5). The glutamate levels increased continuously and reached a peak at the end of $20 \mathrm{~min}$ ischemia. An $\sim 14$-fold increase was observed. After the onset of recirculation, the glutamate levels decreased but did not return to a new stable baseline until the end of the measurement (40 min after recirculation). The glutamate levels at $40 \mathrm{~min}$ after recirculation were significantly higher than the preischemic levels $(p<0.01$; one-way ANOVA; Dunnett's post hoc test).

Glutamate levels in wild-type mice subjected to $20 \mathrm{~min}$ ischemia $(n=8)$ were stable before ischemia. A significant increase in glutamate was detected during ischemia. The increase was acute, but the glutamate levels were significantly lower than the corresponding levels in mice lacking GLT-1 during the first 5 min of 20 min ischemia (Fig. 5), as seen in the experiment of $5 \mathrm{~min}$ ischemia. The increase then became steeper, and the glutamate levels crossed the levels in GLT-1 mutant mice. The glutamate levels increased continuously and reached a peak at the end of $20 \mathrm{~min}$ ischemia. An 80-fold increase was observed. The glutamate lev- 


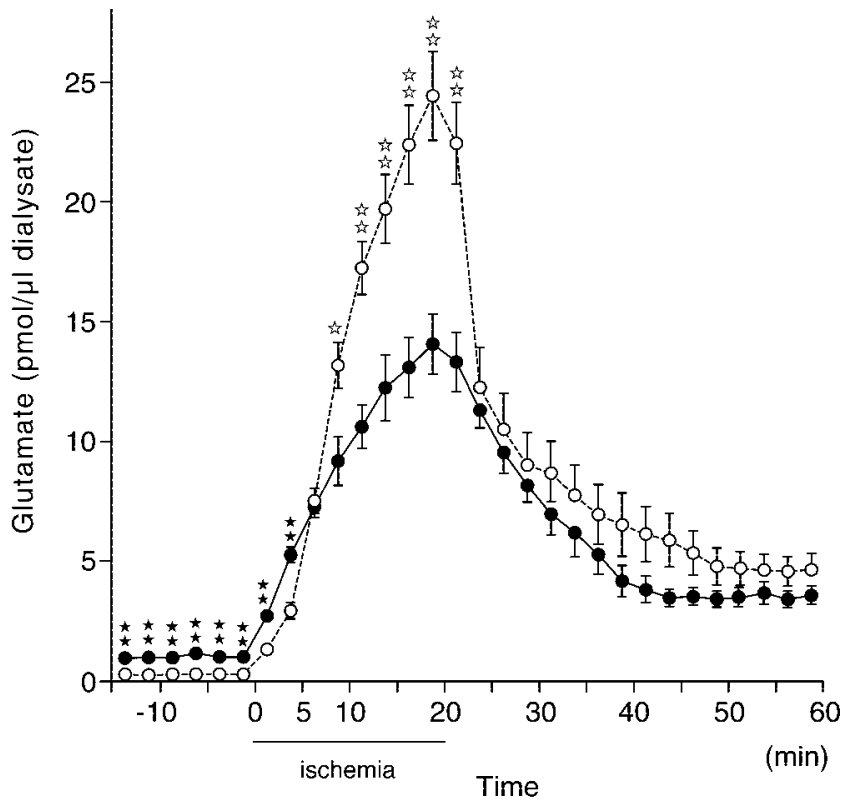

Figure 5. Changes in dialysate levels of glutamate in the hippocampal CA1 of mice lacking GLT-1 and wild-type mice. The mice lacking GLT-1 $(n=8 ;-0)$ and wild-type mice $(n=8$; $\bigcirc-O)$ were subjected to $20 \mathrm{~min}$ ischemia. The data presented are means \pm SEM (bars). Filled asterisks indicate a value significantly higher than the corresponding value in wild-type mice ( $\star \star p<0.01$; two-way ANOVA; Scheffé's post hoc test), and open asterisks indicate a value significantly higher than the corresponding value in mice lacking GLT-1 ( 0.05; two-way ANOVA; Scheffé's post hoc test). Ordinate, Glutamate levels ( $\mathrm{pmol} / \mu \mathrm{l}$ ) in dialysate; abscissa, time ( $\mathrm{min}$ ) before and after the onset of $20 \mathrm{~min}$ ischemia.

els in wild-type mice were significantly higher than the corresponding levels in GLT-1 mutant mice during the last $12.5 \mathrm{~min}$ of ischemia. After the onset of recirculation, the glutamate levels did not remarkably decrease for the first $2.5 \mathrm{~min}$ but started to decrease $2.5 \mathrm{~min}$ after recirculation. The glutamate levels did not return to a new stable baseline until the end of the measurement (40 min after recirculation). The glutamate levels at $40 \mathrm{~min}$ after recirculation were significantly higher than the preischemic levels $(p<0.01$; one-way ANOVA; Dunnett's post hoc test). Eventually, the glutamate levels in wild-type mice were significantly higher than those in mice lacking GLT-1 during the last $12.5 \mathrm{~min}$ of ischemia and the first $2.5 \mathrm{~min}$ of recirculation, whereas the glutamate levels in mice lacking GLT-1 were significantly higher than those in wild-type mice before ischemia and during the first 5 min of ischemia (two-way ANOVA; Scheffé's post hoc test) (Fig. 5).

\section{Neuronal damage induced by $20 \mathrm{~min}$ ischemia}

In GLT-1 mutant mice subjected to $20 \mathrm{~min}$ ischemia, neuronal damage was seen in the CA1 $1 \mathrm{hr}$ after recirculation. Normalappearing neurons, which were densely observed in the CA1 pyramidal cell layer in sham-operated control mice (Fig. $6 a$ ), were rarely seen in the CA1 (Fig. 6b). Many pyknotic nuclei and damaged neurons were seen. Pyknotic nuclei were surrounded by empty spaces, and numerous dark granules in the cytoplasm (selective chromatolysis) (Kirino and Sano, 1984) were observed in many damaged CA1 neurons.

In wild-type mice subjected to $20 \mathrm{~min}$ ischemia, neuronal damage was seen in the CA1 $1 \mathrm{hr}$ after recirculation. Normalappearing neurons were rarely seen in the CA1 (Fig. 6c). Most CA1 neurons showed darkly stained, shrunken cell bodies with surrounding empty spaces.

No significant differences in the number of normal-appearing
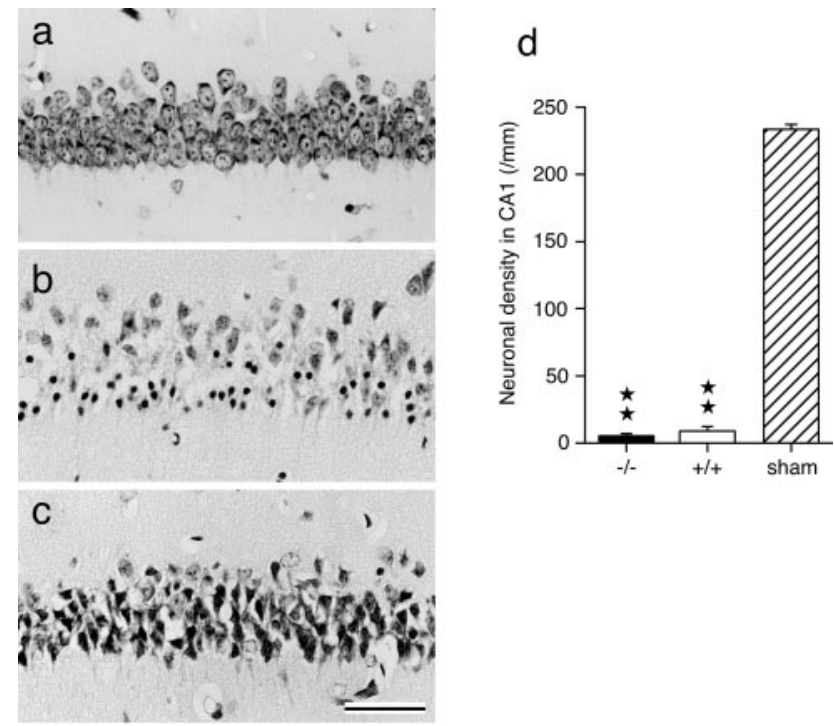

Figure 6. Neuronal death and density in the hippocampal CA1 in mice subjected to $20 \mathrm{~min}$ ischemia. Acute neuronal death was observed $1 \mathrm{hr}$ after recirculation in mice subjected to 20 min ischemia. Normal-appearing neurons, which were densely observed in the CA1 pyramidal cell layer in sham-operated control mice ( $a$ ), were rarely seen in the CA1 of mice lacking GLT-1 (b) and also wild-type mice (c). Scale bar, $50 \mu \mathrm{m}$. $d$, The density of normal-appearing neurons per millimeter of the pyramidal cell layer was calculated in the CA1 in mice lacking GLT-1 $(-/-$, filled columns), wild-type mice $(+/+$, open columns), and sham-operated control mice (sham, stippled columns) $1 \mathrm{hr}$ after recirculation. The sham-operated control mice were $+/+$. Asterisks indicate a value significantly lower than the corresponding value of shamoperated control mice ( $\star \star p<0.01$; one-way ANOVA; Scheffé's post hoc test). Values are means \pm SEM (bars) (each column, $n=8$ ).

neurons were detected between GLT-1 mutant mice $(5.1 \pm 0.7 /$ $\mathrm{mm})$ and wild-type mice $(9.0 \pm 2.6 / \mathrm{mm})$, and the neuronal densities in GLT-1 mutant and wild-type mice subjected to $20 \mathrm{~min}$ ischemia were significantly less than those observed in shamoperated control mice ( $p<0.01$; one-way ANOVA; Scheffé's post hoc test) (Fig. 6d).

\section{Discussion}

In the present study, we performed an in vivo brain microdialysis study and evaluated the functional role of the glial glutamate transporter during ischemia by the comparison of extracellular glutamate levels in the hippocampal CA1 of GLT-1 mutant mice with those of wild-type mice.

\section{Glutamate levels under normal conditions}

The present study showed that the preischemic basal levels of extracellular glutamate in the hippocampal CA1 of GLT-1 mutant mice were significantly higher than those of wild-type mice. This result provides direct evidence that GLT-1 removes glutamate from the extracellular fluid in the hippocampal CA1 to maintain extracellular glutamate at low levels under normal conditions, which has been widely presumed but not proved directly.

\section{Glutamate levels during $5 \mathrm{~min}$ ischemia}

The present study demonstrated that glutamate levels in the hippocampal CA1 of wild-type mice were significantly lower than those of mice lacking GLT-1 during $5 \mathrm{~min}$ ischemia and quickly decreased immediately after recirculation. The result suggests that GLT-1 normally operates to take up extracellular glutamate during and immediately after $5 \mathrm{~min}$ ischemia. In addition, it was shown that delayed neuronal death was induced in the CA1 of GLT-1 mutant mice subjected to $5 \mathrm{~min}$ ischemia. In the present 
study, delayed neuronal death means that morphological damage in ischemic neurons is delayed (Kirino, 1982). It has been known that delayed neuronal death is not produced in the CA1 of C57BL/6 mice subjected to $5 \mathrm{~min}$ ischemia (Kawahara et al., 2002) as shown here. The present study also showed that delayed neuronal death was induced in the CA3 when GLT-1 was eliminated. The histological results suggest that GLT-1 prevents delayed neuronal death induced by $5 \mathrm{~min}$ ischemia in the CA1 and CA3 of mice. Together, these results suggest that GLT-1 takes up extracellular glutamate normally under the ischemic condition produced by $5 \mathrm{~min}$ ischemia and works to prevent the glutamate neurotoxicity. This idea is supported by the following observation using antisense oligodeoxynucleotides: rats infused with GLT-1 antisense oligodeoxynucleotides show a significant increase in the cortical and striatal infarct volume after transient focal cerebral ischemia (Rao et al., 2001).

If GLT-1, which is localized to astrocytes, is not releasing glutamate during $5 \mathrm{~min}$ ischemia, what is responsible for the glutamate increase? It may be caused by neurons. Consistent with this idea, no significant increase in extracellular glutamate was observed during $5 \mathrm{~min}$ ischemia in the gerbil hippocampal CA1, in which most of the neurons had been eliminated before the experiment (Mitani et al., 1994). It has been reported that intracellular glutamate concentration in neurons is so high because neuronal glutamate transporters operate near equilibrium (Kanai et al., 1995; Rothstein et al., 1996), and glutamate can be released more easily from neurons than astrocytes during ischemia, because the high intracellular glutamate concentration drives the reversed operation more readily (Rossi et al., 2000). Furthermore, neurons have been reported to have negligible glycogen, which is the major energy reservoir in the brain, whereas astrocytes contain substantial amounts of glycogen and can use glycogen under low oxygen circumstances (Swanson and Choi, 1993; Rose et al., 1998), suggesting that neurons could suffer in energy depletion more easily than astrocytes during ischemia. The failure of cellular energy induces dysfunction of the $\mathrm{Na}^{+}-\mathrm{K}^{+}$pump and reduction of the $\mathrm{Na}^{+}$gradient, leading to reversed transporters and the release of glutamate into extracellular space (Kauppinen et al., 1988; Szatkowski et al., 1990; Attwell et al., 1993). Electrophysiological studies have supportively observed that ischemiainduced glutamate release is caused by reversed neuronal glutamate transporters in hippocampal slices subjected to in vitro ischemia (Rossi et al., 2000; Hamann et al., 2002). Their in vitro ischemic conditions may correspond to the present in vivo ischemic condition during $5 \mathrm{~min}$ ischemia.

The electrophysiological studies have also reported that a GLT-1 blocker and GLT-1 mutation have no effect on the glutamate-evoked current in ischemic neurons (Rossi et al., 2000; Hamann et al., 2002). These reports suggest that GLT-1 played a lesser role in their experiments. This might be explained by the ideas that GLT-1 is not expressed abundantly in the 2-week-old animals used in their experiments, as pointed out by the authors themselves (Hamann et al., 2002), and that a substantial part of the released glutamate may be washed out with perfusate in the in vitro chamber.

\section{Glutamate levels during $20 \mathrm{~min}$ ischemia}

The experiment of $20 \mathrm{~min}$ ischemia revealed that glutamate levels in the hippocampal CA1 of wild-type mice were significantly higher than those of mice lacking GLT-1 during the last $12.5 \mathrm{~min}$ of ischemia. In addition, increased glutamate levels in wild-type mice did not remarkably decrease for the first $2.5 \mathrm{~min}$ after recirculation, compared with the second $2.5 \mathrm{~min}$ after recirculation. If
GLT-1 works normally at the end of ischemia, increased glutamate levels would quickly decrease immediately after the onset of recirculation. Therefore, GLT-1 may induce dysfunction. In vitro studies have shown that glutamate release is produced by reversed operation of glutamate transporters under energydepleted conditions (Kauppinen et al., 1988; Szatkowski et al., 1990; Attwell et al., 1993). The present result that glutamate levels in wild-type mice were significantly higher than those in mice lacking GLT-1 strongly suggests that the reversed operation of glial glutamate transporters occurs in the in vivo ischemic condition produced by $20 \mathrm{~min}$ ischemia. This idea is in accordance with the following pharmacological observation: the GLT-1 blocker DL-threo- $\beta$-benzyloxyaspartate reduces the ischemiainduced glutamate release in rat cortical superfusates during 20 min global brain ischemia (Phillis et al., 2000).

In GLT-1 mutant mice, the ischemia-induced glutamate level was approximately one-half of that in wild-type mice at the end of $20 \mathrm{~min}$ ischemia. However, the histological study did not show any reduction in ischemic neuronal damage at $1 \mathrm{hr}$ after recirculation. The acute death of CA1 neurons was induced in the GLT-1 mutant mice as well as in the wild-type mice. This may be explained by a quantitative dose-toxicity study. It has been shown that neurotoxicity in the cortical cell culture is produced by a 5 min exposure to $\mathrm{ED}_{50}$ of $50-100 \mu \mathrm{M}$ glutamate (Choi et al., 1987). Therefore, in the present study, extracellular glutamate concentrations higher than neurotoxic levels would be continued longer than $5 \mathrm{~min}$ in the hippocampal CA1 of both GLT-1 mutant and wild-type mice during $20 \mathrm{~min}$ ischemia.

In summary, our present results suggest that the function of GLT-1 changes from neuroprotective to neurodegenerative during ischemia: GLT-1 takes up extracellular glutamate to protect neurons against delayed neuronal death during the first $5 \mathrm{~min}$ of ischemia and then releases glutamate, triggering acute neuronal death, during the last $12.5 \mathrm{~min}$ of $20 \mathrm{~min}$ ischemia in the in vivo hippocampal CA1. These findings favor therapeutic strategies aimed at preventing or reducing the excessive release of glutamate in the ischemic brain by modulating glutamate transport. Allosteric GLT-1 activators, such as bromocryptine (Yamashita et al., 1995), may be useful in preventing brain damage in the early stage of ischemia. In contrast, the design of GLT-1 reversal inhibitors may present a novel strategy for the development of drugs to minimize brain damage in the late stage of ischemia.

\section{References}

Arriza JL, Eliasof S, Kavanaugh MP, Amara SG (1997) Excitatory amino acid transporter 5, a retinal glutamate transporter coupled to a chloride conductance. Proc Natl Acad Sci USA 94:4155-4160.

Attwell D, Barbour B, Szatkowski M (1993) Nonvesicular release of neurotransmitter. Neuron 11:401-407.

Chaudhry FA, Lehre KP, van Lookeren Campagne M, Ottersen OP, Danbolt NC, Storm-Mathisen J (1995) Glutamate transporters in glial plasma membranes: highly differentiated localizations revealed by quantitative ultrastructual immunocytochemistry. Neuron 15:711-720.

Choi DW, Rothman SM (1990) The role of glutamate neurotoxicity in hypoxic-ischemic neuronal death. Annu Rev Neurosci 13:171-182.

Choi DW, Maulucci-Gedde M, Kriegstein AR (1987) Glutamate neurotoxicity in cortical cell culture. J Neurosci 7:357-368.

Fairman WA, Vandenberg RJ, Arriza JL, Kavanaugh MP, Amara SG (1995) An excitatory amino-acid transporter with properties of a ligand-gated chloride channel. Nature 375:599-603.

Fujii M, Hara H, Meng W, Vonsattel JP, Huang Z, Moskowitz MA (1997) Strain-related differences in susceptibility to transient forebrain ischemia in SV-129 and C57black/6 mice. Stroke 28:1805-1811.

Hamann M, Rossi DJ, Marie H, Attwell D (2002) Knocking out the glial glutamate transporter GLT-1 reduces glutamate uptake but does not af- 
fect hippocampal glutamate dynamics in early simulated ischaemia. Eur J Neurosci 15:308-314.

Kanai Y, Hediger MA (1992) Primary structure and functional characterization of a high-affinity glutamate transporter. Nature 360:467-471.

Kanai Y, Nussberger S, Romero MF, Boron WF, Hebert SC, Hediger MA (1995) Electrogenic properties of the epithelial and neuronal high affinity glutamate transporter. J Biol Chem 270:16561-16568.

Kanai Y, Trotti D, Nussberger S, Hediger MA (1997) The high affinity glutamate transporter family. In: Neurotransmitter transporters: structure, function, and regulation (Reith MEA, ed), pp171-213. Totowa, NJ: Humana.

Kaplan TM, Lasner TM, Nadler JV, Crain BJ (1989) Lesions of excitatory pathways reduce hippocampal cell death after transient forebrain ischemia in the gerbil. Acta Neuropathol (Berl) 78:283-290.

Kato T, Berger SJ, Carter JA, Lowry OH (1973) An enzymatic cycling method for nicotinamide-adenine dinucleotide with malic and alcohol dehydrogenases. Anal Biochem 53:86-97.

Kauppinen RA, McMahon HT, Nicholls DG (1988) $\mathrm{Ca}^{2+}$-dependent and $\mathrm{Ca}^{2+}$-independent glutamate release, energy status and cytosolic free $\mathrm{Ca}^{2+}$ concentration in isolated nerve terminals following metabolic hypoglycaemia and anoxia. Neuroscience 27:175-182.

Kawahara N, Kawai K, Toyoda T, Nakatomi H, Furuya K, Kirino T (2002) Cardiac arrest cerebral ischemia model in mice failed to cause delayed neuronal death in the hippocampus. Neurosci Lett 322:91-94.

Kirino T (1982) Delayed neuronal death in the gerbil hippocampus following ischemia. Brain Res 239:57-69.

Kirino T, Sano K (1984) Selective vulnerability in the gerbil hippocampus following transient ischemia. Acta Neuropathol (Berl) 62:201-208.

Kuroiwa T, Bonnekoh PB, Hossmann K-A (1992) Laser doppler flowmetry in CA1 sector of hippocampus and cortex after transient forebrain ischemia in gerbils. Stroke 23:1349-1354.

Lehre KP, Danbolt NC (1998) The number of glutamate transporter subtype molecules at glutamatergic synapses: chemical and stereological quantification in young adult rat brain. J Neurosci 18:8751-8757.

Lehre KP, Levy LM, Ottersen OP, Storm-Mathisen J, Danbolt NC (1995) Differential expression of two glial glutamate transporters in the rat brain: quantitative and immunocytochemical observations. J Neurosci 15:1835-1853.

Mitani A, Kubo H, Iga K, Imon H, Kadoya F, Kataoka K (1990) A new enzymatic cycling technique for glutamate determination in brain microdialysates. J Neurochem 54:709-711.

Mitani A, Andou Y, Kataoka K (1992) Selective vulnerability of hippocampal CA1 neurons cannot be explained in terms of an increase in glutamate concentration during ischemia in the gerbil: brain microdialysis study. Neuroscience 48:307-313.

Mitani A, Andou Y, Matsuda S, Arai T, Sakanaka M, Kataoka K (1994) Origin of ischemia-induced glutamate efflux in the CA1 field of the gerbil hippocampus: an in vivo brain microdialysis study. J Neurochem 63:2152-2164.

Mitani A, Watanabe M, Kataoka K (1998a) Functional changes of NMDA receptors related to enhancement of susceptibility to neurotoxicity in the developing pontine nucleus. J Neurosci 18:7941-7952.

Mitani A, Namba S, Ikemune K, Yanase H, Arai T, Kataoka K (1998b) Postischemic enhancements of N-methyl-D-aspartic acid (NMDA) and nonNMDA receptor-mediated responses in hippocampal CA1 pyramidal neurons. J Cereb Blood Flow Metab 18:1088-1098.

Nitsch C, Okada Y (1979) Distribution of glutamate in layers of the rabbit hippocampal fields CA1, CA3, and the dentate area. J Neurosci Res 4:161-167.

Panahian N, Yoshida T, Huang PL, Hedley-Whyte ET, Dalkara T, Fishman MC, Moskowitz MA (1996) Attenuated hippocampal damage after global cerebral ischemia in mice mutant in neuronal nitric oxide synthase. Neuroscience 72:343-354.

Peghini P, Janzen J, Stoffel W (1997) Glutamate transporter EAAC-1deficient mice develop dicarboxylic aminoaciduria and behavioral abnormalities but no neurodegeneration. EMBO J 16:3822-3832.

Pellegrini-Giampietro DE, Zukin RS, Bennett MVL, Cho S, Pulsinelli WA (1992) Switch in glutamate receptor subunit gene expression in CA1 subfield of hippocampus following global ischemia in rats. Proc Natl Acad Sci USA 89:10499-10503.
Phillis JW, Ren J, O’Regan MH (2000) Transporter reversal as a mechanism of glutamate release from the ischemic rat cerebral cortex: studies with DL-threo- $\beta$-benzyloxyaspartate. Brain Res 868:105-112.

Pines G, Danbolt NC, Bjørås M, Zhang Y, Bendaham A, Eide L, Koepsell H, Storm-Mathisen J, Seeberg E, Kanner BI (1992) Cloning and expression of a rat brain L-glutamate transporter. Nature 360:464-467.

Pow DV, Barnett NL, Penfold P (2000) Are neuronal transporters relevant in retinal glutamate homeostasis? Neurochem Int 37:191-198.

Rao VLR, Dogan A, Todd KG, Bowen KK, Kim B-T, Rothstein JD, Dempsey RJ (2001) Antisense knockdown of the glial glutamate transporter GLT-1, but not the neuronal glutamate transporter EAAC1, exacerbates transient focal cerebral ischemia-induced neuronal damage in rat brain. J Neurosci 21:1876-1883.

Riepe RE, Norenburg MD (1977) Müller cell localization of glutamine synthetase in rat retina. Nature 268:654-655.

Rose CR, Waxman SG, Ransom BR (1998) Effects of glucose deprivation, chemical hypoxia, and simulated ischemia on $\mathrm{Na}^{+}$homeostasis in rat spinal cord astrocytes. J Neurosci 18:3554-3562.

Rossi DJ, Oshima T, Attwell D (2000) Glutamate release in severe brain ischaemia is mainly by reverse uptake. Nature 403:316-321.

Rothman SM, Olney JW (1986) Glutamate and the pathophysiology of hypoxic-ischemic brain damage. Ann Neurol 19:105-111.

Rothstein JD, Martin L, Levey AI, Dykes-Hoberg M, Jin L, Wu D, Nash N, Kuncl RW (1994) Localization of neuronal and glial glutamate transporters. Neuron 13:713-725.

Rothstein JD, Dykes-Hoberg M, Pardo CA, Bristol LA, Jin L, Kuncl RW, Kanai Y, Hediger MA, Wang Y, Schielke JP, Welty DF (1996) Knockout of glutamate transporters reveals a major role for astroglial transport in excitotoxicity and clearance of glutamate. Neuron 16:675-686.

Storck T, Schulte S, Hofmann K, Stoffel W (1992) Structure, expression, and functional analysis of a $\mathrm{Na}^{+}$-dependent glutamate/aspartate transporter from rat brain. Proc Natl Acad Sci USA 89:10955-10959.

Storm-Mathisen J, Danbolt NC, Rothe F, Torp R, Zhang N, Aas J-E, Kanner BI, Langmoen I, Ottersen OP (1992) Ultrastructural immunocytochemical observations on the localization, metabolism and transport of glutamate in normal and ischemic brain tissue. Prog Brain Res 94:225-241.

Swanson RA, Choi DW (1993) Glial glycogen store affect neuronal survival during glucose deprivation in vitro. J Cereb Blood Flow Metab 13:162-169.

Szatkowski M, Barbour B, Attwell D (1990) Non-vesicular release of glutamate from glial cells by reversed electrogenic glutamate uptake. Nature 348:443-446

Tanaka K (1993) Expression cloning of a rat glutamate transporter. Neurosci Res 16:149-153.

Tanaka K (2000) Functions of glutamate transporters in the brain. Neurosci Res 37:15-19.

Tanaka K, Watase K, Manabe T, Yamada K, Watanabe M, Takahashi K, Iwama H, Nishikawa T, Ichihara N, Kikuchi T, Okuyama S, Kawashima N, Hori S, Takimoto M, Wada K (1997) Epilepsy and exacerbation of brain injury in mice lacking the glutamate transporter GLT-1. Science 276:1699-1702.

Von Lubitz DKJE, Lin RCS, Jacobson KA (1995) Cerebral ischemia in gerbils: effects of acute and chronic treatment with adenosine $\mathrm{A}_{2 \mathrm{~A}}$ receptor agonist and antagonist. Eur J Pharmacol 287:295-302.

Voutsinos-Porche B, Bonvento G, Tanaka K, Steiner P, Welker E, Chatton J-Y, Magistretti PJ, Pellerin L (2003) Glial glutamate transporters mediated a functional metabolic crosstalk between neurons and astrocytes in the mouse developing cortex. Neuron 37:275-286.

Wieloch T, Lindvall O, Blomqvist P, Gage FH (1985) Evidence for amelioration of ischaemic neuronal damage in the hippocampal formation by lesions of the perforant path. Neurol Res 7:24-26.

Yamashita H, Kawakami H, Zhang YX, Tanaka K, Nakamura S (1995) Neuroprotective mechanism of bromocriptine. Lancet 346:1305.

Yang G, Kitagawa K, Matsushita K, Mabuchi T, Yagita Y, Yanagihara T, Matsumoto M (1997) C57BL/6 strain is most susceptible to cerebral ischemia following bilateral common carotid occlusion among seven mouse strains: selective neuronal death in the murine transient forebrain ischemia. Brain Res 752:209-218. 